\title{
RESULTS FROM THE I.A.G.P. FLOW-LINE STUDY INLAND OF GASEY, WILKES LAND, ANTARGTICA
}

\author{
By W. F. Budd and N. W. Young \\ (Antarctic Division, Department of Science, 568 St Kilda Road, Melbourne, Victoria 3004, \\ Australia)
}

\begin{abstract}
In order to determine accurate velocities of the ice sheet in the interior of Antarctica, approximately along a flow line, a detailed trilateration net was established in 1973 from the summit of Law Dome ( $100 \mathrm{~km}$ inland) to about $250 \mathrm{~km}$ south near the $2000 \mathrm{~m}$ contour. The net consisted of a double line of markers approximately $10 \mathrm{~km}$ apart with all sides and diagonals of the quadrilaterals measured with tellurometers. In addition, satellite doppler survey positions and astronomical azimuths were determined at about $50 \mathrm{~km}$ intervals to control the net on the large scale. Other measurements carried out en route included: continuous barometric levelling, radio echo-sounding, gravimetry, accumulation, and surface sampling. The route was close to an earlier traverse route which reached Vostok in 1962 and along which other data, including snow-surface temperatures and temperature-depth gradients, were determined.

The trilateration net was re-surveyed in 1975 allowing velocities and strain-rates to be determined. The results indicate that the ice sheet is close to balance in this region.

Therefore, the measured velocities were used together with "balance velocities", further inland, to carry out a modelling study of a flow line, to derive particle trajectories, ages, temperature profiles, and "dynamics velocities", from a flow law. The results provide further insight into the dynamics and flow properties of the ice sheet.
\end{abstract}

RÉsumé. Résultats des études d'écoulement de l'I.A.G.P., au droit de Casey, Wilkes Land, Antarctique. En vue de déterminer avec précision les vitesses de la calotte glaciaire dans l'intérieur de l'Antarctique, approximativement le long d'une ligne de courant, on a établi en 1973 une triangulation détaillée depuis le sommet de Law Dome (100 km à l'intérieur des terres) jusqu'à environ $250 \mathrm{~km}$ au Sud, près de la cote $2000 \mathrm{~m}$. Le réseau comprend une double ligne de balises distantes d'environ $10 \mathrm{~km}$ avec tous les côtés et les diagonales mesurés au telluromètre. De plus des positions par visée sur satellite Doppler et des azimuths astronomiques furent relevés à des intervalles de $50 \mathrm{~km}$ environ pour contrôler le réseau à plus grande échelle. D'autres mesures menées au passage comprenaient: des relevés barométriques continus, des sondages par écho radio, des mesures de gravimétrie, des prélèvements d'échantillons de surface et de l'accumulation. L'itinéraire débouche sur un itinéraire transversal précédent qui atteignit Vostok en 1962 et le long duquel d'autres données, dont les températures de surface de la neige et les gradients de température en profondeur avaient

Le réseau de triangulation fut à nouveau ré-observé en 1975 ce qui a permis de déterminer les vitesses et le champ des contraintes. Les résultats indiquent que la calotte glaciaire est proche de l'équilibre dans cette région.

C'est pourquoi les vitesses mesurées furent utilisées concuremment aux "vitesses de bilan" vers l'intérieur du continent pour mettre au point un modèle d'étude d'une ligne de courant, afin de tirer d'une loi d'écoulement, les trajectoires des particules, leurs âges, les profils de température et les "vitesses dynamiques". Les résultats offrent une vue plus complète de la dynamique et des propriétés rhéologiques des calottes glaciaires.

Zusammenfassung. Ergebnisse der I.A.G.P.-Stromlinienstudie landeinwärts von Casey, Wilkes Land, Antarktis. Zur genauen Bestimmung von Geschwindigkeiten in Innern des antarktischen Eisschildes, annähernd längs einer Stromlinie, wurde 1973 ein engmaschiges Trilaterationsnetz vom Scheitel des Law Dome (Ioo km landeinwärts) bis ca. $250 \mathrm{~km}$ nach Süden nahe der Meereshöhe $2000 \mathrm{~m}$ aufgebaut. Das Netz bestand aus einer Doppellinie von Festpunkten im Abstand von ca. $10 \mathrm{~km}$, in der alle Seiten und Diagonalen der Quadratkette mit Tellurometern gemessen wurden. Zusätzlich wurden Positionen durch Dopplermessungen nach Satelliten und astronomische Azimute in Abständen von etwa $50 \mathrm{~km}$ zur grossmassstäbigen Kontrolle des Netzes bestimmt. Weitere Messungen während der Feldkampagne umfassten: fortlaufende barometrische Höhenmessung, Dickenbestimmung mit Radar-Echo, Gravimetrie, Akkumulation und Probenentnahme an der Oberfläche. Die Route verlief nahe einer früheren Überquerung, die 1962 in Vostok endete und bei der andere Daten wie Schneetemperaturen und Temperaturgradienten in die Tiefe bestimmt worden waren.

Die Wiederholung der Trilateration im Jahre 1975 erlaubte die Bestimmung von Geschwindigkeiten und Verformungsraten. Die Ergebnisse deuten darauf hin, dass sich der Eisschild in dieser Region nahe am
Gleichgewichtszustand befindet.

Die gemessenen Geschwindigkeiten wurden daher zusammen mit "Gleichgewichtsgeschwindigkeiten" von weiter landeinwärts dazu benutzt, eine Modellstudie für eine Stromlinie durchzuführen, sowie Teilchenbahnen, Altersangaben, Temperaturprofile und "dynamische Geschwindigkeiten" aus einem Fliessgesetz herzuleiten. Die Ergebnisse vermitteln weitere Einsichten in die Dynamik und Fliessverhältnisse des Eisschildes. 
The AIMS OF The I.A.G.P. AND PROGRESS TO DATE

The International Antarctic Glaciological Project (I.A.G.P.) was set up in r97o to co-ordinate a multi-national study of a large section of East Antarctica between long. $90^{\circ}$ and $160^{\circ} \mathrm{E}$. The organization and aims have been given in the Polar Record (Anonymous, 1971). Details of the techniques have been given by Bentley and others (1972). A summary of the status to 1976 has been made by Radok (1977).

In brief, the major aims are to determine the present dynamics and state of balance of the ice sheet and to see what can be learned of the past history of the ice sheet, and climate, from deep core studies. Because the present state of balance and the past history both involve the flow of the ice and its causes, the project requires fundamental knowledge of ice-mass dynamics.

In order to study the past history, it is necessary to know how to calculate velocities and what factors need to be known. In particular, the stress, temperature and ice structure are important, so these need to be determined. The present ice sheet provides a test for any model of ice flow by a comparison of calculated surface velocities with observed velocities. The temperature distribution is obviously important here. Hence it is necessary to determine the data required to compute the temperature distribution which can then be checked against observed temperature profiles through the ice sheet. The temperature distribution is affected by the flow of the ice sheet and also by past climate and ice-sheet changes. It is understood that deep profiles of isotope ratios from ice cores may enable these factors to be taken into account.

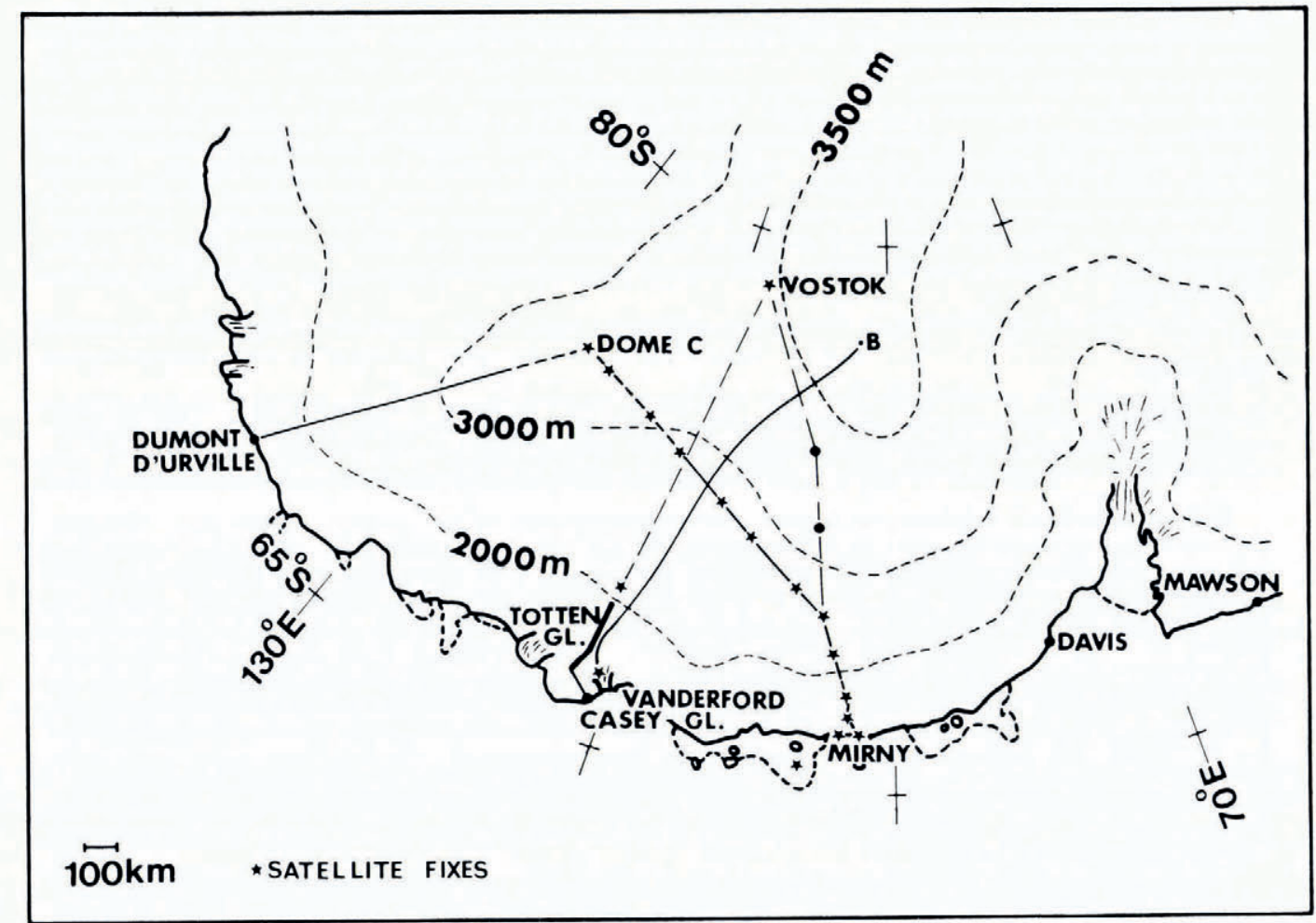

Fig. I. The map of the I.A.G.P. ara a shows the elevation contours, the trilateration net inland of Casey (thick line), the approximate flow line modelled from ridge " $B$ ", and other traverse routes with satellite fixes for ice movement as marked. 
The I.A.G.P. then requires large areal coverage for ice thickness, surface elevation, and accumulation-rates. Detailed flow-line studies are required to understand the present dynamics. Deep ice-sheet properties are to be studied by cores from large numbers of shallow holes, a number of intermediate holes particularly along flow lines, and at least a few deep holes to near bed in key locations.

At present the three detailed flow-line studies envisaged are (cf. Fig. I), those inland of Mirny, Casey, and Dumont d'Urville stations. It is proposed to tie these detailed flow-line studies together by approximate contour-type traverses.

This paper presents a summary to date of the work carried out for the flow-line study inland of Casey.

\section{Pre-I.A.G.P. WORK in the Region AND SubSequent I.A.G.P. AGtivities}

Traverses were made by the Australian National Antarctic Research Expeditions (A.N.A.R.E.) inland of Casey in $1960,196 \mathrm{r}$, and 1962 , reaching lat. $69^{\circ} \mathrm{S} ., 7 \mathrm{I}^{\circ} \mathrm{S}$. and Vostok (lat. $78^{\circ} 4 \mathrm{o}^{\prime} \mathrm{S}$.), respectively. Results from this work have been reported by Black and Budd (1964), Budd (rg66, I969), Battye (unpublished), and Walker (rg66, unpublished). The parameters measured included: snow accumulation, surface mean temperature, surface . elevation, ice thickness, snow density and stratigraphy, and temperature gradients to $60 \mathrm{~m}$ depth.

The ice-thickness measurements were by seismic soundings each $32 \mathrm{~km}$, and gravity measurements at $1.6 \mathrm{~km}$ intervals. Beyond lat. $7 \mathrm{I}^{\circ} \mathrm{S}$., however, the noise in the seismic records was high and the echoes not clear. Nevertheless, the ice thicknesses determined by Walker have generally been confirmed by subsequent radio echo-sounding reported by Drewry (1975).

A similar set of data had also been collected by the Soviet expeditions inland of Mirny as far as Vostok, Sovietskaya, and the highest part of the ice sheet en route to the Pole of Relative Inaccessibility.

These data provided sufficient information to estimate steady state or "balance" velocities and also the temperature distributions, cf. Budd (1969), Shumskiy (r970), Budd and others (I97I).

The most important missing data required to check the modelling were the surface velocities. In addition, new techniques and other developments provided the opportunity to give a much better coverage by co-operation. This included aerial sounding for surface elevation and ice thickness, deep core drilling, stable and unstable isotope studies, and satellite doppler survey techniques.

Consequently, detailed flow-line studies have commenced inland of Mirny, Casey, and Dumont d'Urville. Deep core drilling has been undertaken at Vostok and Dome "C", and a connecting traverse has been made from Pionerskaya to Dome " $\mathrm{C}$ ".

Broad-scale aerial sounding has been carried out over the area to about long. $100^{\circ} \mathrm{E}$., $\mathrm{cf}$. Drewry (1975), and Robin and others (1977). This has provided basic data that define the large-scale contours of the region.

\section{The I.A.G.P. Flow-Line STUdy inland of CASEY}

The first I.A.G.P. traverse inland of Casey was commenced in 1971. Prior expeditions had established the ice movement to the summit of Law Dome, roo km inland (cf. Budd, r97o[b]) which is a stationary position. In $197 \mathrm{I}$, techniques were developed and tried for establishing a connected, double-braced survey net using tellurometers. To carry this out a party at each corner of the quadrilateral was required. This system was used to establish the first quadrilateral south of Law Dome summit in $197 \mathrm{r}$ but problems with vehicles prevented further extension that year. 
In 1973, the system worked well, extending the net to the bottom of the valley, about $60 \mathrm{~km}$ south, in autumn, and on to $25^{\circ} \mathrm{km}$ south of Law Dome summit, reaching lat. $69^{\circ} \mathrm{S}$. near the $2000 \mathrm{~m}$ elevation contour in spring-summer. The party included a surveyor from the U.S. Geological Survey (U.S.G.S.) by co-operation with the U.S. National Science Foundation (N.S.F.), to operate a "geoceiver" satellite survey set. The geoceiver obtained precise locations at a number of points of the survey net, as shown in Figure 2.

Other measurements made en route included radio echo-sounding along each side of the net, continuous recording barometric levelling, gravimetry, surface sampling, snow accumulation, astronomical position locations, and azimuths.

In 1975, the net was almost completely re-surveyed by the same technique. Again, a surveyor with a geoceiver was provided by the U.S.G.S. and N.S.F. The previous locations

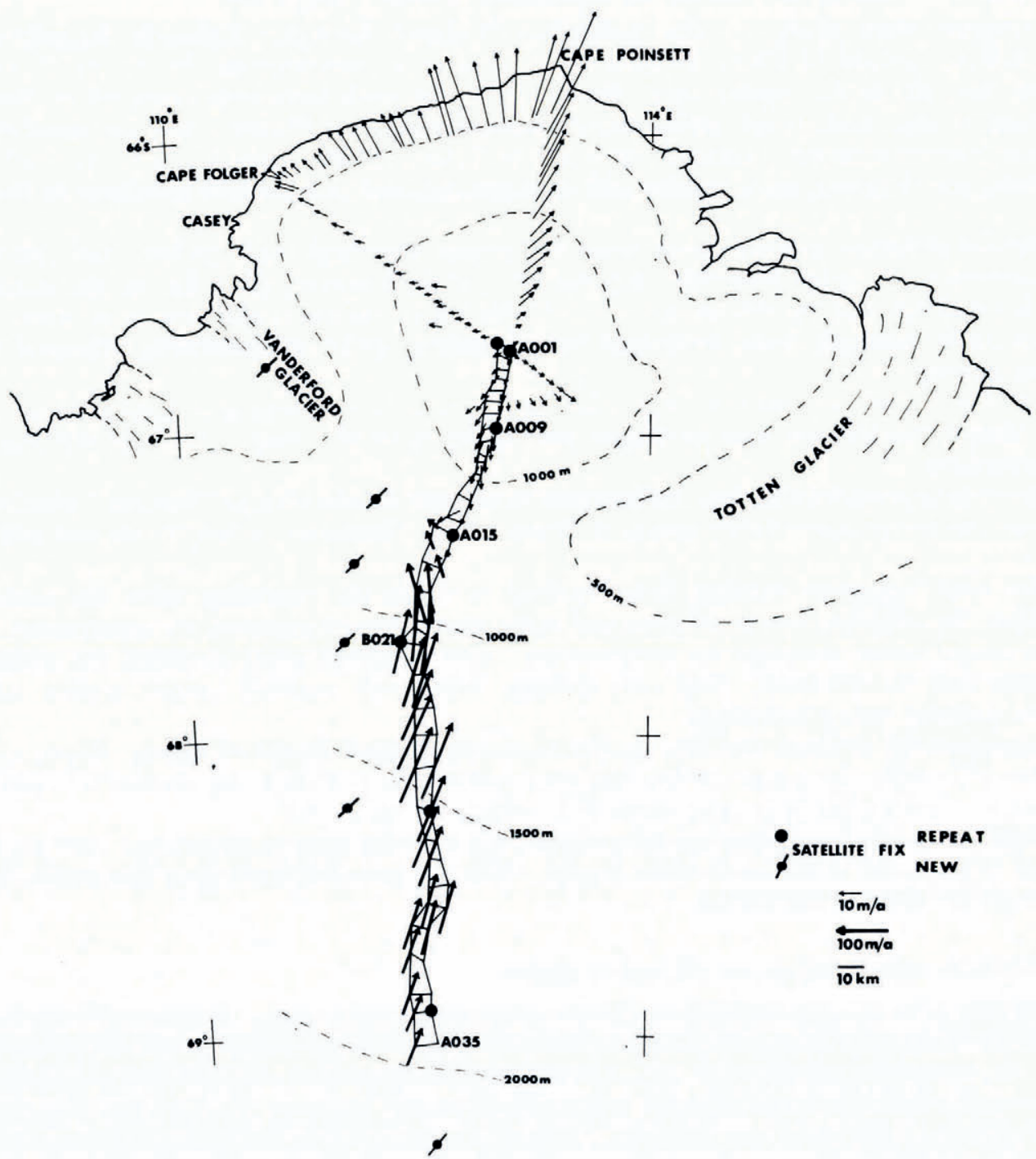

Fig. 2. The derived ice-velocity vectors inland of Casey are shown together with the tellurometer trilateration net and the locations of the satellite doppler fixes. 
were re-measured and provided movement results and checks of the survey control in comparison with the tellurometer results with astronomical azimuth.

A number of the $9 \mathrm{~m}$ marker poles could not be re-located, probably due to breakage, bending, or separation of the $3 \mathrm{~m}$ sections. New poles were established and the grid continued. This meant that the velocities and strain-rates in a few locations were lost. Nevertheless, the survey maintained high precision and as a result accurate strain-rates and velocities were obtained from the differences over 2 years.

In 1976 , it was planned to extend the net farther south but vehicle trouble occurred which made it more convenient to fill in all the gaps to Ao26 and to establish off-set stations to the west to give further large-scale information. In addition, a detailed study over a large undulation between $\mathrm{Ao22}$ and $\mathrm{Bo2} 3$ was carried out.

For 1978 , the plan is to extend the survey farther south but, instead of using a continuous trilateration net, satellite doppler techniques will be used to establish precise locations at about $50 \mathrm{~km}$ intervals. At these sites strain grids are to be established by tellurometer, and other measurements will include surface sampling.

Barometric levelling and radio echo-sounding is being carried out en route. Already during autumn one new station has been established about $40 \mathrm{~km}$ south of the 1973 net.

\section{DEEP STRUGTURE FROM ICE-CORE DRILLING PROGRAMMES}

So far, the Casey I.A.G.P. flow-line study has been primarily concerned with surface observations, including temperature profiles to $60 \mathrm{~m}$ depth. It is also of interest to obtain information on the deep properties of the ice by core drilling, to study, in particular, the icecrystal and flow properties, as well as the past history of the ice sheet. Drilling through a substantial part of the ice thickness in the inland area would be a large and difficult undertaking. Hence, at this stage, as much support information as practical is being collected prior to any drilling to enable clearer understanding of where drilling sites would be most advantageous. In the meantime, an intermediate drilling programme is being carried out on Law Dome with the A.N.A.R.E. thermal drill which has a capacity to reach $475 \mathrm{~m}$ depth. This capability allows a substantial programme to be carried out to study the deep structure of the Law Dome ice cap, which abuts the I.A.G.P. flow-line area in the area of the VanderfordTotten Glaciers trench. It is expected that the Law Dome drilling programme can provide much basic general information on present ice properties and past history of the ice sheet which is also directly relevant to the I.A.G.P. flow-line study.

So far, the Law Dome core-drilling programme has been reasonably successful in already providing substantial information on past history (cf. Budd and Morgan, I977), the temperature structure to test thermodynamics calculations (Budd and others, 1976), and the crystallography and flow properties (Russell-Head and Budd, 1979). These latter results can be incorporated into the modelling of the flow line to help interpret the measured ice velocities.

\section{RESULTS FROM THE FIELD WORK}

\section{Elevation and ice thickness}

Only a brief summary of the major results can be given here. Full details of the data from the different years are in preparation as A.N.A.R.E. reports.

From the elevation and ice-thickness measurements along the two lines, plots of the icesurface and bedrock elevation are derived, as a function of distance south, resolved from the two sides of the net, and these are given in Figure 3. A remarkable feature of the surface is the dominance of undulations of the order of several times the ice thickness as described earlier in this area by Black and Budd (1964). These features were a major cause of irregularities in the trilateration net which needed intervisibility between the corners to be maintained. 


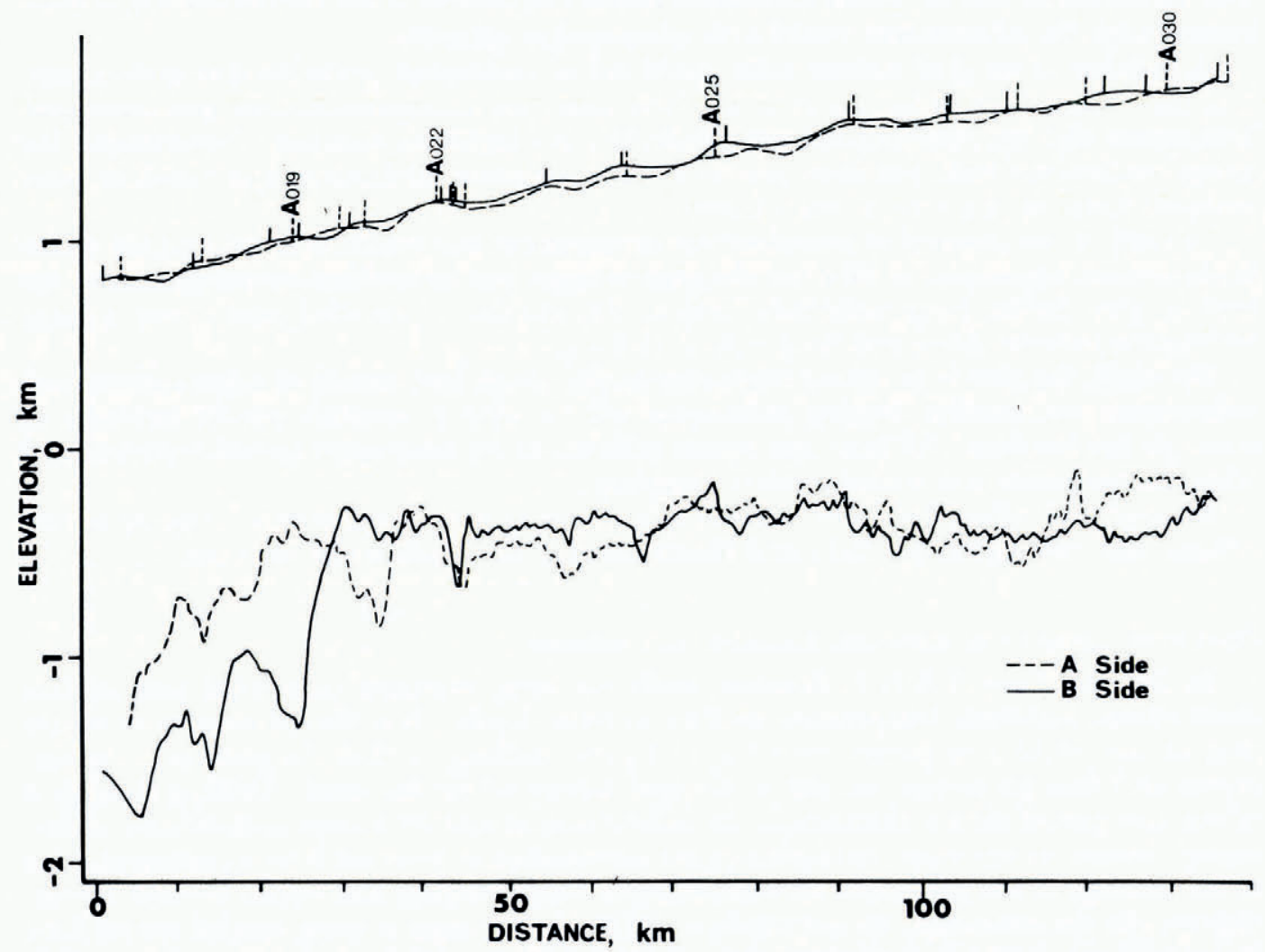

Fig. 3. A section of the surface and bedrock profiles along the trilateration net for the east side $(A)$ and west side $(B)$ from AoI 7 to Ao3I is shown resolved as a function of distance south. The movement poles are shown as numbered sequentially except for extra markers in the valley south of Ao22.

It is apparent that the surface and bed are generally related but with the bed much rougher over a wide range of scales. This is similar to the results reported for Law Dome by Budd and Carter (197I). Here we are mainly interested in the large-scale smoothed results over the order of ten ice thicknesses or more. However, a detailed study in the line of flow over a large wave (A023-Bo23) has now been undertaken to test theories of the type discussed by Budd (1968, I970[a], I971). The off-set stations established during 1976 help provide larger-scale contour data for the interpretation of the ice-flow convergence or divergence.

\section{Velocities and strain-rates}

The ties between the geoceiver locations and the survey net were within the accuracy of each system $(c . \pm \mathrm{I} \mathrm{m})$. Hence the geoceiver datahave been used to control the large scale for the survey net. The differences in position over the 2 years for each of the re-measured nodes have been calculated and the vector velocities $\left(\mathrm{m} \mathrm{a}^{-1}\right)$ are shown in Figure 2. The magnitudes for the two lines are shown in Figure 4. First, it is notable that the velocities vary smoothly in magnitude and direction. This is because the strain-rates are small and, although highly variable (from positive to negative) over the undulations, they accumulate to smooth velocity variations over large distances. 


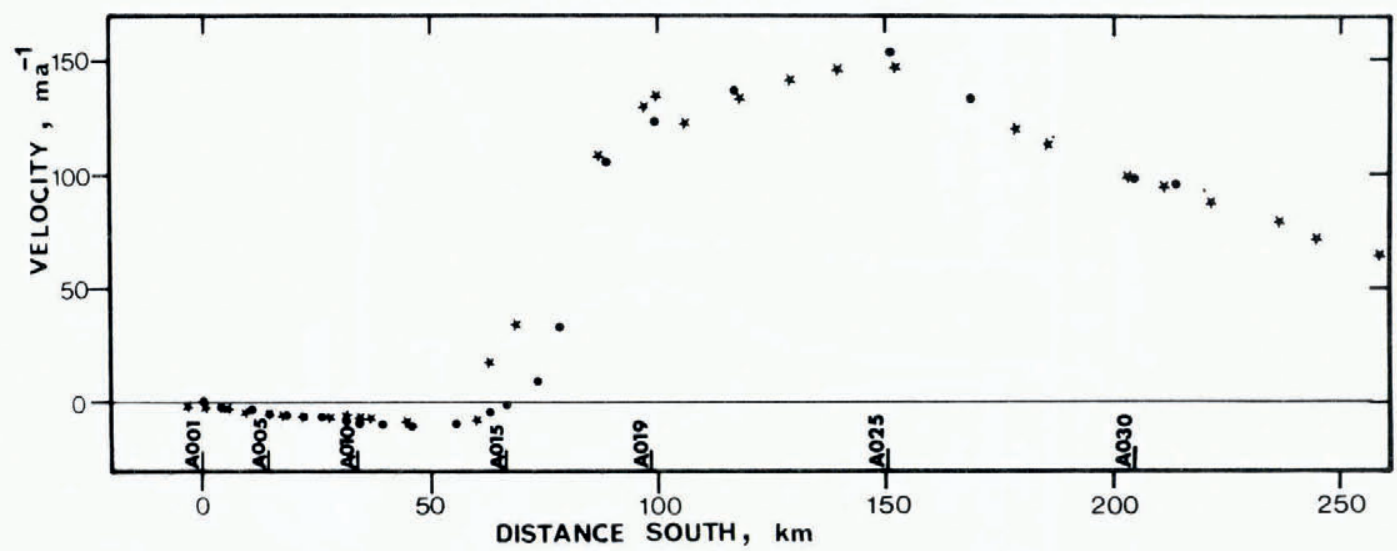

Fig. 4. The magnitudes (northwards) of the velocities measured at the trilateration net marker poles for the $A$ side ( $\bullet$ ) and $B$ side $(\star)$ are shown as a function of distance south from the dome summit (Aoor) to the valley bottom (Aor5) and to the end of the net at Ao35.

To obtain smooth strain-rates, representative of the large scale, measurements over distances of the order of $50 \mathrm{~km}$ are required. This makes the precise doppler survey technique particularly suitable for this type of project, with stations at about $50 \mathrm{~km}$ spacing.

In general, the velocities follow the large-scale orthogonals to the elevation contours with flow slightly from the west of south and turning with divergence near the saddle point to flow into the fast outlet glaciers.

The magnitude of the speed increases from about $60 \mathrm{~m} \mathrm{a}^{-1}$ at $A 035$ to $155 \mathrm{~m} \mathrm{a}^{-1}$ at A025. Hereafter the decrease is associated with the approach to the saddle point. The off-set stations established in 1976 are designed to study the flow into Vanderford Glacier, where the centre-line speed reaches about I $\mathrm{km} \mathrm{a}^{-1}$ (cf. Budd, I966). To study this transition further, a new movement station was established, at $180 \mathrm{~m}$ elevation, near the grounding line on Vanderford Glacier in January 1978.

\section{Accumulation-rates}

The general pattern of accumulation-rates as reported by Black and Budd (1964) has been found to be representative. The nodes of the trilateration net, however, tended to be located near tops of undulations which on the average obtain lower accumulation-rates. The variation in accumulation-rates over the undulations is very large and must be taken into account to obtain representative averages. On the large scale, the average accumulation-rate increases from $0.30 \mathrm{Mg} \mathrm{m}^{-2}$ at Ao35 to $0.75 \mathrm{Mg} \mathrm{m}^{-2}$ in the valley.

\section{Other data}

The mean surface temperatures from bore-hole studies have been reported by Budd (1966, 1969). A summary of the results is included in Figure 5. From the surface samples collected in 1973 the mean oxygen $\left(\delta^{18} \mathrm{O} /{ }^{16} \mathrm{O}\right)$ isotope ratios have been determined as given by Budd and Morgan (1977). The values vary with distance inland from $-22 \%$ at the saddle point ( $800 \mathrm{~m}$ elevation) to $-31 \%$ at $\mathrm{Ao} 35$ ( $1960 \mathrm{~m}$; lat. $69^{\circ} \mathrm{S}$.). There is a further decrease to $-44 \%$ obtained by Young (1979) at lat. $78^{\circ} \mathrm{S}$. on the traverse between Pionerskaya and Dome "C".

The mean temperature-depth gradients between 20 and $60 \mathrm{~m}$ depth have been reported by Budd (1969). These are given in Figure 7 and are discussed below in comparison with the results obtained from the modelling. 


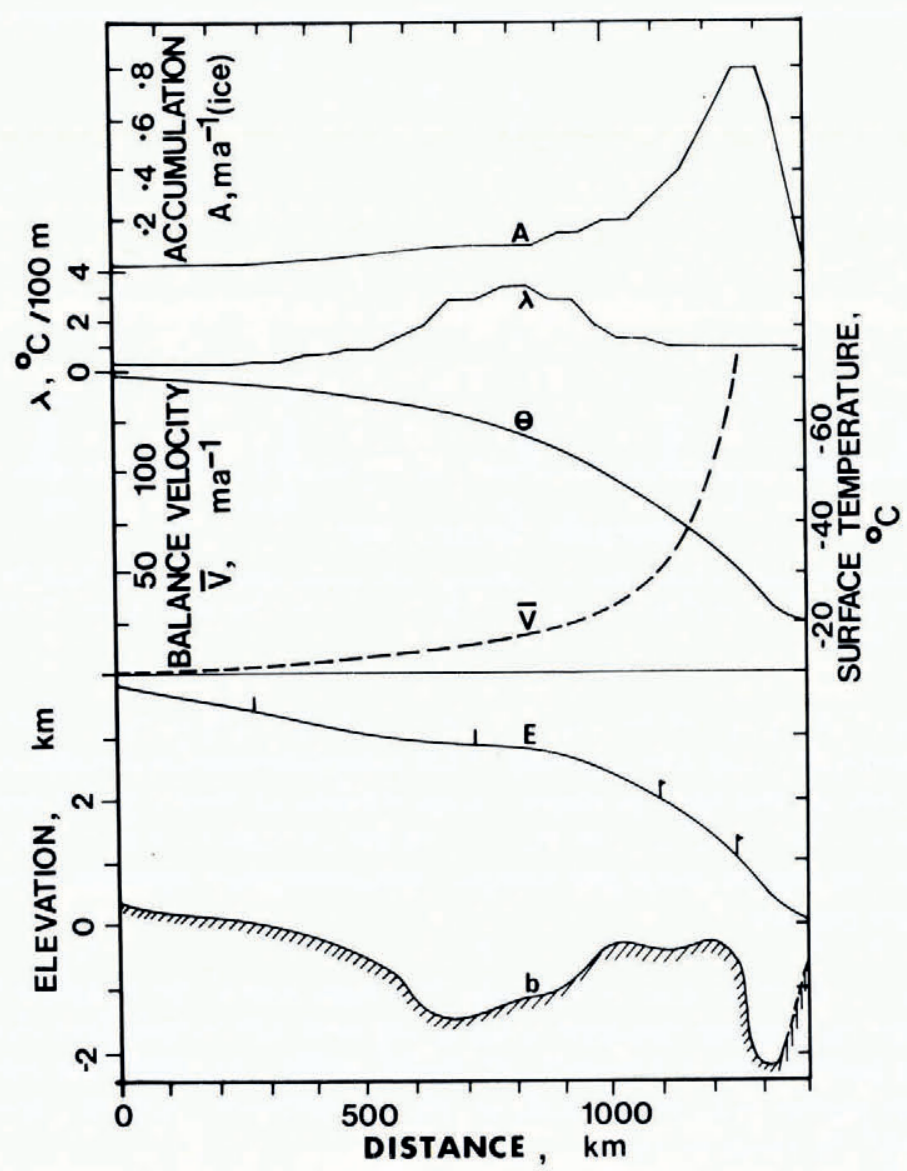

Fig. 5. Data required for the modelling study are shown for the flow line given in Figure I from ridge " $B$ " to Vanderford Glacier: bedrock elevation $(b)$, surface elevation $(E)$, balance velocity $(\bar{V})$, surface temperature $(\theta)$, temperature-elevation gradient $(\lambda)$ and accumulation-rate $(A)$.

\section{Numerical MODELLING STUDIES}

Although it is now clear from the field results that the I.A.G.P. net does not follow the ice flow exactly, the velocity field is smooth and is expected not to vary greatly laterally in the interior. Hence it is considered that flow-line type modelling can provide an indication of the general large-scale flow of the area based on data in the vicinity. The technique used is similar to that described by Budd and others (1971) with modifications as given by Budd and others (1976).

The input data require surface elevation, bedrock elevation, accumulation-rate, surface velocities or ice-flow properties, surface temperature, and the geothermal heat flux. Since the measured velocities correspond closely to the velocities calculated in the area for balance by Budd and others (197I), it has been considered here that balance may be reasonably close and as a result the velocities farther inland can be approximated by balance velocities.

For this flow-line study, an orthogonal to the elevation contours was constructed inland of the I.A.G.P. line which diverted farther to the west than the previous line to Vostok studied by Budd and others (r97r). The accumulation-rates used in the interior were derived from the map produced by Kotlyakov and others (1974). Other data inland of the I.A.G.P. net 
have been taken from Budd and others (I97I) with modifications from more recent work, given by Drewry (1975), for surface and bedrock elevations.

Input data for the modelling were smoothed over about $5^{0} \mathrm{~km}$ intervals to avoid the complications of the small-scale variations.

Various flow-law data have been used to calculate "dynamics" velocities from the shear stress and the computed temperature profiles. Further investigations are proceeding for this work using more recent ice-flow data from Russell-Head and Budd (r979) and Lile (r978, unpublished).

The main outputs from the model include particle paths, ages, temperature profiles, basal melt-rates, and dynamics velocities. At this stage the main comparisons to be made with observation are those of temperature-depth gradients at the surface and the dynamics velocity over the area of the survey net.

\section{RESULTS FROM THE MODELLING STUDIES}

A summary of the results for the particle paths, ages, temperature profiles, and basal temperatures is shown in Figure 6. In comparison with the earlier results of Budd and others (197I), the ages in the lower layer are greater. This is due to lower accumulation-rates in the interior used in this study and also in the velocity and strain-rates decreasing with depth as derived from the flow law using the computed temperatures. The basal temperatures are also higher, with melting setting in at about the $500 \mathrm{~km}$ point. A geothermal heat-flux gradient of $2.2 \mathrm{deg} / \mathrm{l} 00 \mathrm{~m}$ was used. In general, the basal temperature tends to increase in deep regions. The borders of "melt lakes" as described by Robin and others (1977) could be used to calculate geothermal fluxes just required for melting.

The surface temperature-depth gradients show a consistent trend from about + I deg/ roo $\mathrm{m}$ inland to $c$. $-2 \mathrm{deg} / \mathrm{I} 00 \mathrm{~m}$ near the coast. These compare very favourably with the

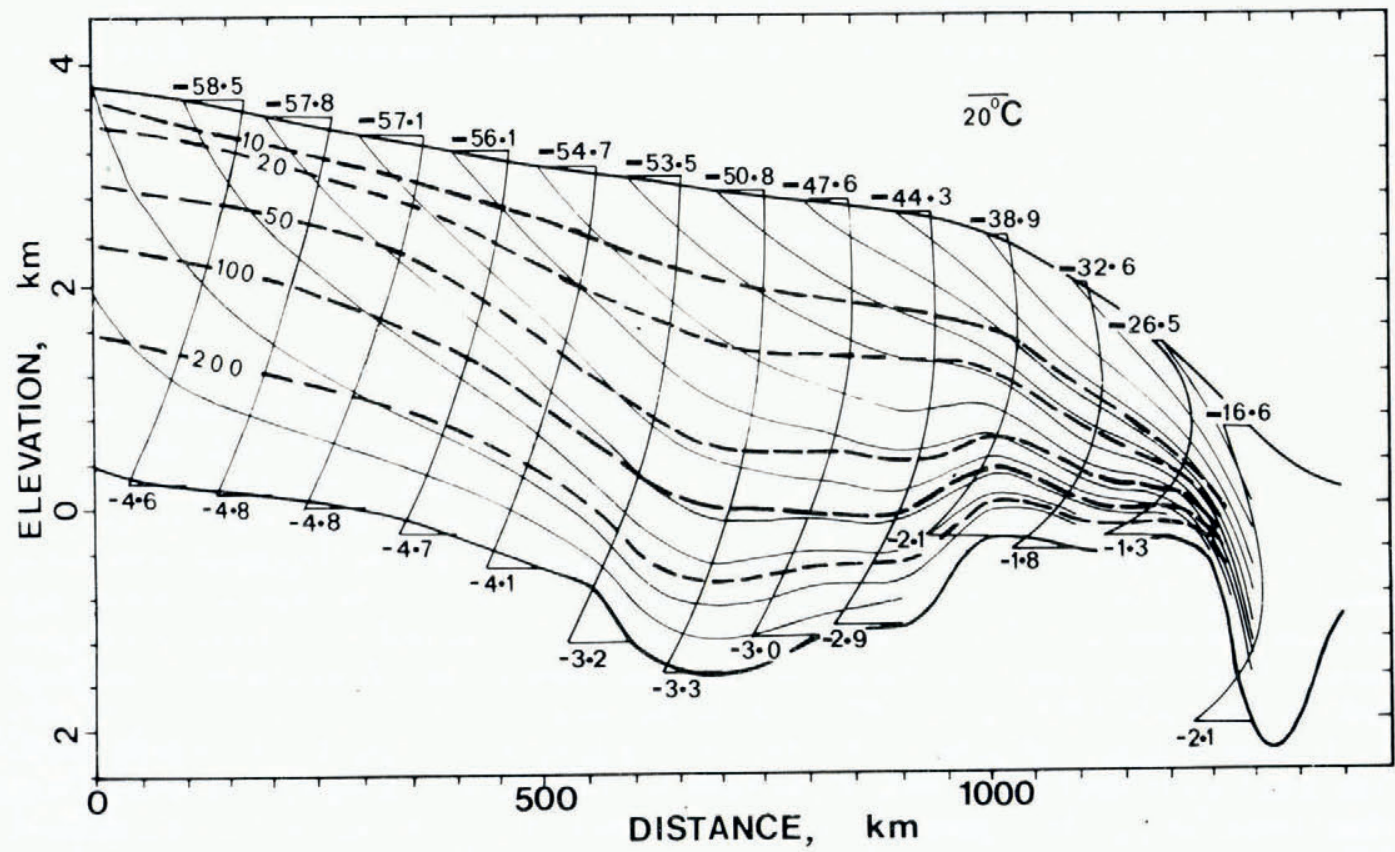

Fig. 6. Results of the flow-line modelling showing the particle trajectories, ages $\left(\mathrm{I}^{3} \mathrm{a}\right.$ ), and temperature profiles, with surface and basal temperatures. The surface temperature-depth gradients show a trend from positive to negative towards the coast. 
measured gradients above $60 \mathrm{~m}$ depth as shown in Figure 7 . There appears to be a net difference between the two of about $0.3-0.5 \mathrm{deg} / 100 \mathrm{~m}$. This is similar to the difference observed in the upper section of the Vostok temperature profile above the steady-state profile computed by Budd and others (1975). This discrepancy can be interpreted in terms of recent surface warming which has also been observed in the Law Dome temperature profiles and elsewhere.

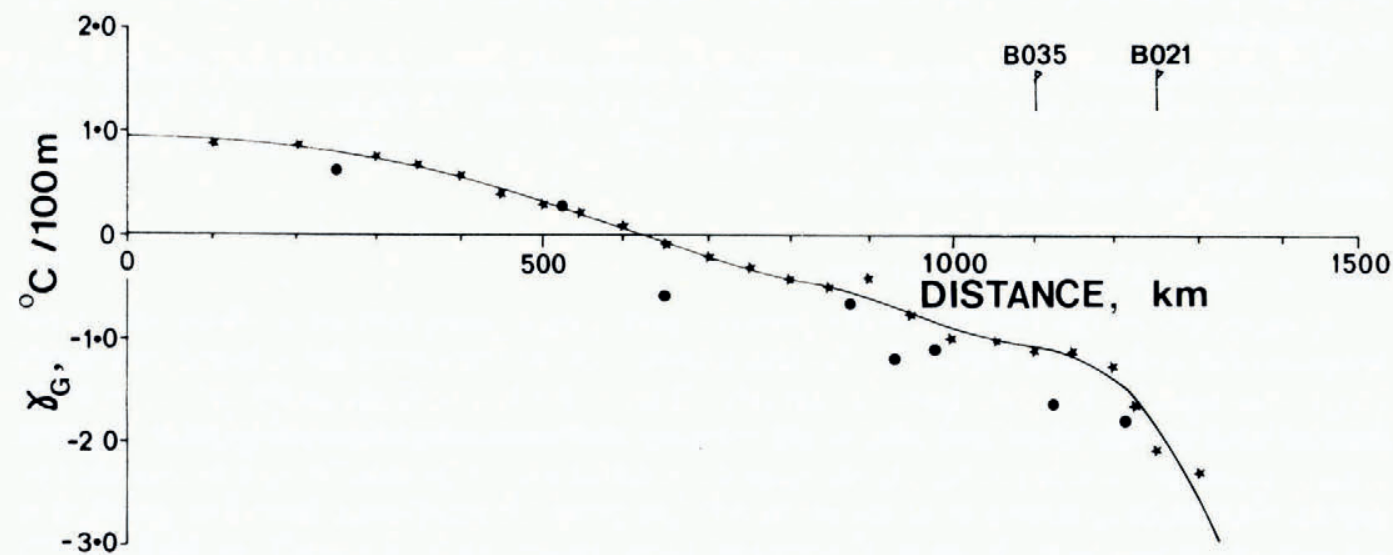

Fig. 7. Temperature-depth gradients along the flow line. The computed gradients $(\star)$ are shown in comparison with gradients (•) measured along the route from Casey towards Vostok by Budd in 1961 and Battye in 1962.

The results of the computed dynamics velocities are shown in comparison with those observed in Figure 8a. In this case, agreement is reasonable for the poor data available for ice flow at low temperatures and stresses. The new data referred to on p. 97 are still under study, including the incorporation of the anisotropic crystallographic effects through an enhancement factor specified as a function of relative depth as given by Russell-Head and Budd (1979). Even with this modification, to obtain agreement between the observed and computed velocities, in the area of Ao35, where the shear stress levels out and the velocity increases, it has been found necessary to include the longitudinal stresses in the octahedral shear stress to calculate the shear strain-rate.

\section{OUTLET-GLAGIER FLOW}

From the above results it appears that the dynamics of the ice mass along the flow line are quite understandable in terms of the computed temperatures and measured ice-flow properties. Even where basal melting occurs, bottom sliding is probably negligible. As the coast is approached, however, the ice is channelled into the deep troughs of Vanderford and Totten Glaciers, where the ice velocities increase about an order of magnitude. At the same time the basal shear stress decreases. This phenomenon can only be explained in terms of basal sliding. This situation for the fast outlet glaciers is similar to the way in which sliding velocities increase with decreasing shear stress when accompanied by decreasing effective normal load in experiments described by Budd and others (1979). A similar effect has been used by Budd and McInnes ([ $\left.{ }^{\mathrm{C}} \mathrm{I}_{978}\right)$ in modelling surges.

In order to study this phenomenon further, additional velocity markers have been established on Vanderford Glacier, as shown in Figure 2. These serve to determine the velocity and shear stress through the transition from slow to fast flow. It is recommended that many more such outlet-glacier studies be made in other locations to help clarify the dynamics of the phenomenon. 


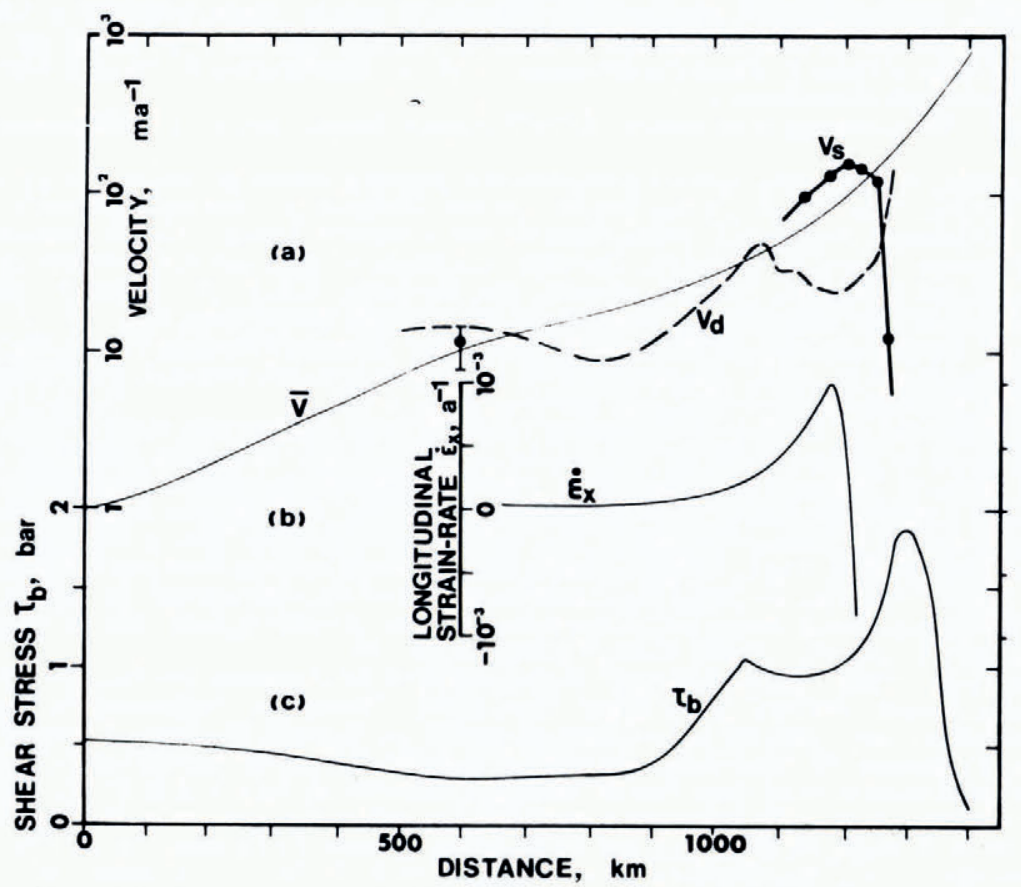

Fig. 8. The flow-line model output "dynamics velocity" $\left(V_{\mathrm{d}}\right)$ is shown in comparison with the input "balance velocity" $(\bar{\nabla})$ and the measured surface velocity $V_{\mathrm{s}}$. . The measured longitudinal strain-rate $\dot{\epsilon}_{x}$, and the basal shear stress $\tau_{\mathrm{b}}$ are also shown.

\section{Acknowledgements}

The authors wish to express appreciation for the important contribution of the "geoceiver" measurements made possible through the U.S. National Science Foundation Division of Polar Programs, and the U.S. Geological Survey.

The success of the field programme has been made possible by the active support of a large number of A.N.A.R.E. expeditioners for which we are especially grateful. In particular, the traverse science teams which obtained the essential data for the results reported here were as follows: for 1973: R. M. Lightfoot (leader), I. E. Holmes, A. L. Foster, B. D. Taylor, D. A. Bruce,* R. Wilson (U.S.G.S.); for 1975: B. R. Harrison (leader), R. J. Paynting, C. J. Gamgee, M. Kros, * R. J. Neff (U.S.G.S.); and for 1976 : P. L. Keage (leader), T. G. Brooks and L. O. Blakeley.

Thanks are also due to the Australian Division of National Mapping who provided surveyors $\left({ }^{*}\right)$ and also carried out the survey net analysis.

\section{REFERENCES}

Anonymous. 1971. International Antarctic Glaciological Project. Polar Record, Vol. 15, No. 98, p. 829-33. Battye, A. C. Unpublished. Glaciological studies made at Wilkes in 1962 . [M.Sc. thesis, University of Melbourne, 1964.]

Bentley, C. R., and others. 1972. The International Antarctic Glaciological Project standardisation document, by C. R. Bentley, W. F. Budd, V. M. Kotlyakov, C. Lorius, and G. de Q. Robin. Polar Record, Vol. I6, No. 101, p. $349-64$.

Black, H. P., and Budd, W. F. 1964. Accumulation in the region of Wilkes, Wilkes Land, Antarctica. Journal of Glaciology, Vol. 5, No. 37, p. 3-16.

Budd, W. F. 1966. Glaciological studies in the region of Wilkes, eastern Antarctica, 1961. ANARE Scientific Reports. Ser. A(IV). Glaciology. Publication No. 88. 
Budd, W. F. I968. The longitudinal velocity profile of large ice masses. Union de Géodésie et Géophysique Internationale. Association Internationale d'Hydrologie Scientifique. Assemblée générale de Berne, 25 sept.-7 oct. 1967. [Commission de Neiges et Glaces.] Rapports et discussions, p. 58-77. (Publication No. 79 de l'Association Internationale d'Hydrologie Scientifique.)

Budd, W. F. 1969. The dynamics of ice masses. ANARE Scientific Reports. Ser. A(IV). Glaciology. Publication No. 108.

Budd, W. F. I970[a]. Ice flow over bedrock perturbations. Fournal of Glaciology, Vol. 9, No. 55, p. 29-48.

Budd, W. F. I970[b]. The Wilkes ice cap project. [Union Géodésique et Géophysique Internationale. Association Internationale d'Hydrologie Scientifique.] [International Council of Scientific Unions. Scientific Committee on Antarctic Research. International Association of Scientific Hydrology. Commission of Snow and Ice.] International Symposium on Antarctic Glaciological Exploration (ISAGE), Hanover, New Hampshire, U.S.A., 3-7 September 1968, p. 414-29. [(Publication No. 86 [de l'Association Internationale d'Hydrologie Scientifique].)]

Budd, W. F. 197 I. Stress variations with ice flow over undulations. Fournal of Glaciology, Vol. 10, No. 59, p. 1 77-95.

Budd, W. F., and Carter, D. B. 1971. An analysis of the relation between the surface and bedrock profiles of ice caps. Fournal of Glaciology, Vol. 10, No. 59, p. 197-209.

Budd, W. F., and McInnes, B. J. [ ${ }^{\mathrm{C}}{ }_{1}$ 978.] Modelling surging glaciers and periodic surging of the Antarctic ice sheet. (In Pittock, A. B., and others, ed. Climatic change and variability. A southern perspective. Editors: A. B. Pittock, L. A. Frakes, D. Jenssen, 7. A. Peterson, 7. W. Zillman on behalf of the Australian Branch, Royal Meteorological Society. Based on a conference at Monash University, Melbourne, Australia, 7-12 December 1975, which was co-sponsored by the Australian Academy of Science. Cambridge, etc., Cambridge University Press, p. 228-33.)

Budd, W. F., and Morgan, V. I. 1977. Isotopes, climate, and ice sheet dynamics from core studies on Law Dome, Antarctica. [Union Géodésique et Géophysique Internationale. Association Internationale des Sciences Hydrologiques. Commission des Neiges et Glaces.] Symposium. Isotopes et impuretés dans les neiges et glaces. Actes du colloque de Grenoble, août/septembre 1975, p. 312-21. (IAHS-AISH Publication No. 118. )

Budd, W. F., and others. 1971. Derived physical characteristics of the Antarctic ice sheet, by W. F. Budd, D. Jenssen, and U. Radok. ANARE Interim Reports. Ser. A(IV). Glaciology. Publication No. 120.

Budd, W. F., and others. I 975. Raschet temperaturnogo profilya po dannym skvazhiny na stantsii Vostok. [By] W. F. Budd, D. Jenssen, N. W. Young. Informatsionnyy Byulleten' Sovetskoy Antarkticheskoy Ekspeditsii, No. 9o, p. 50-58. [English translation in Soviet Antarctic Expedition Information Bulletin, Vol. 8, No. 12, 1976, p. 668-73.]

Budd, W. F., and others. I 976 . Measured and computed temperature distributions in the Law Dome ice cap, Antarctica, by W. F. Budd, N. W. Young, and C. R. Austin. Fournal of Glaciology, Vol. 16, No. 74, p. 99-1 ro.

Budd, W. F., and others. 1979. Empirical studies of ice sliding, by W. F. Budd, P. L. Keage, and N. A. Blundy. Fournal of Glaciology, Vol. 23, No. 89, p. I $57-70$.

Drewry, D. J. 1975. Radio echo sounding map of Antarctica, ( $\sim 90^{\circ}$ E-180 $)$. Polar Record, Vol. 17, No. 109, p. $359-74$.

Kotlyakov, V. M., and others. 1974. Novaya karta pitaniya lednikovogo pokrova Antarktidy [New map of the accumulation on the Antarctic ice sheet]. [By] V. M. Kotlyakov, N. I. Barkov, I. A. Loseva, V. N. Petrov. Materialy Glyatsiologicheskikh Issledovaniy. Khronika. Obsuzhdeniya, Vyp. 24, p. 248-55.

Lile, R. C. 1978. The effect of anisotropy on the creep of polycrystalline ice. Fournal of Glaciology, Vol. 21, No. 85, p. $475-83$.

Lile, R. C. Unpublished. The rheology of polycrystalline ice. [Ph.D. thesis, University of Melbourne, I978.]

Radok, U. 1977. International Antarctic Glaciological Project: past and future. Antarctic Journal of the United States, Vol. 12, Nos. 1-2, p. 32-38.

Robin, G. de Q., and others. 1977. International studies of ice sheet and bedrock, by G. de Q. Robin, D. J. Drewry, and D. T. Meldrum. Philosophical Transactions of the Royal Society of London, Ser. B, Vol. 279, No. 963, p. $185-96$.

Russell-Head, D. S., and Budd, W. F. 1979. Ice-sheet flow properties derived from bore-hole shear measurements combined with ice-core studies. Fournal of Glaciology, Vol. 24, No. 90, p. I 1 7-30.

Shumskiy, P. A. I970. The Antarctic ice sheet. [Union Géodésique et Géophysique Internationale. Assaciation Internationale d'Hydrologie Scientifique.] [International Council of Scientific Unions. Scientific Committee on Antarctic Research. International Association of Scientific Hydrology. Commission of Snow and Ice.] International Symposium on Antarctic Glaciological Exploration (ISAGE), Hanover, New Hampshire, U.S.A., 3-7 September 1968, p. 327-47. [(Publication No. 86 [de l'Association Internationale d'Hydrologie Scientifique].)]

Walker, D. J. 1966. Wilkes geophysical surveys, Antarctica 1962. Canberra, Bureau of Mineral Resources. Geology and Geophysics. Dept. of National Development. (Records No. 1966/129.)

Walker, D. J. Unpublished. Glaciological and geophysical studies in Wilkes Land, Antarctica, 1962/63. [M.Sc. thesis, University of Melbourne, 1966.]

Young, N. W. r 979 . Measured velocities of interior East Antarctica and the state of mass balance within the I.A.G.P. area. Journal of Glaciology, Vol. 24, No. 90, p. 77-87.

\section{DISGUSSION}

T. J. Hughes: Are you implying that the "height above buoyancy" used to specify the normal stress in your sliding model is related to the height above sea-level for ice-stream sliding? If so, then ice streams B and C entering the Ross Ice Shelf from West Antarctica should have comparable sliding velocities. Rose and Thomas did not find that. In particular, Rose 
described a nearly flat portion of ice stream C about 200 or $300 \mathrm{~km}$ from its grounding line, and the height above buoyancy must be quite different for that location and the grounding line. Yet there is no indication of different sliding velocities (from crevasse densities, for example). How exactly do you determine the "height above buoyancy" in your sliding model? Is it inferred from field velocity data, or can it be independently calculated to give velocities independent of field data?

W. F. BudD: If the ice is resting on bedrock below sea-level and the basal water layer is connected to the sea, the normal stress above buoyancy is calculated from the overburden of the ice above that which is required to just ground the ice below sea-level. In the Byrd Land ice streams the basal shear stress tends to decrease with decreasing normal stress above buoyancy towards the grounding line.

I. M. Whillans: Do you take the subglacial water pressure as that which would be associated with a simple connection to the sea? If so, how is it possible to have the lakes (such as those near Dome "G")?

Have you made rough calculations to determine if longitudinal stress gradients can explain the up-hill flow?

BuDD: The high sliding velocities of Antarctic outlet glaciers are associated with low basal shear stress in areas where the bedrock is well below sea-level. I suggest the cause is associated with the low normal stress (above buoyancy) as found with the ice-sliding measurements. As regards the proposed "lakes" in the interior, I would not wish to speculate about the ice-flow regime until further investigations have been made.

Yes, the up-hill flow can be explained by longitudinal strain-rate gradients. A case of the type found on the I.A.G.P. flow line inland of Casey was discussed in the context of ice flow over bedrock perturbations (Budd, I970[a]). 